\title{
EFEKTIVITAS KONSELING PERILAKU DENGAN TEKNIK DISENSITISASI SISTEMATIS UNTUK MENGURANGI DAMPAK TRAUMA PADA ANAK KORBAN PERCERAIAN DI DESA BANTENGAN KECAMATAN BANDUNG
}

\author{
Yuli Dwi Susanti, Wikan Galuh Widyarto \\ Institut Agama Islam Negeri Tulungagung, Indonesia \\ yulisusanti417@gmail.com
}

\begin{abstract}
This study aims to determine the impact of trauma on child victims of divorce and to determine the effectiveness of behavioral counseling with systematic sensitization techniques to reduce the impact of trauma on child victims of divorce in Bantengan Village, Bandung District. The method used is quantitative with a pre-experimental design with the type of one group pre-test post-test design. In selecting the subject by using purposive sampling method. Using four techniques in data collection, namely observation, interviews, documentation and questionnaire. This research was conducted in Bantengan Village, Bandung District. While the samples taken were 8 children who had high trauma impacts due to divorce victims. In data analysis using paired sample t-test and hypothesis testing using the SPSS version 26 application. The results of the study showed a significant difference in the changes in the impact of trauma in children who had been given group behavior counseling services using systematic sensitization techniques. From the results of the calculation of the paired sample ttest, the significance value (2-tailed) $0.000<0.05$, which means that $H_{a}$ is accepted and $H_{0}$ is rejected. This means that group behavior counseling services with systematic sensitization techniques can reduce the impact of trauma on child victims of divorce in Bantengan Village, Bandung District.
\end{abstract}

Keywords : Trauma, Systematic Sensitization Technique, Child.

\begin{abstract}
Abstrak
Penelitian ini bertujuan untuk mengetahui bagaimana dampak trauma pada anak korban perceraian dan untuk mengetahui efektivitas konseling perilaku dengan teknik disensitisasi sistematis untuk mengurangi dampak trauma pada anak korban perceraian di Desa Bantengan Kecamatan Bandung. Metode yang digunakan adalah kuantitatif dengan desain pre-eksperimen dengan jenis one group pre-test post-test design. Dalam pemilihan subjek dengan dilakukan menggunakan metode purposive sampling. Menggunakan empat teknik dalam pengumpulan data yaitu observasi, wawancara,dokumentasi dan angket. Penelitian ini dilakukan di Desa Bantengan Kecamatan Bandung. Populasi yang digunakan dalam penelitian ini adalah anak korban perceraian di Desa Bantengan yang berjumlah 40 anak. Sedangkan sampel yang diambil berjumlah 8 anak yang mempunyai dampak trauma tinggi akibat korban perceraian. Dalam analisis data menggunakan uji paired sample t-test dan uji hipotesis dengan menggunakan aplikasi SPSS versi 26. Hasil dari penelitian menunjukkan perbedaan yang signifikan terhadap perubahan dampak trauma pada anak yang telah diberikan layanan konseling perilaku kelompok dengan teknik disensitisasi sistematis. Dari hasil perhitungan uji paired sample t-test didapatkan nilai signifikansi (2-tailed) 0,000 < 0,05 yang mempunyai arti bahwa $H_{a}$ diterima dan $H_{0}$ ditolak. Hal tersebut dapat diartikan bahwa layanan konseling perilaku kelompok dengan teknik disensitisasi sistematis dapat mengurangi dampak trauma pada anak korban perceraian di Desa Bantengan Kecamatan Bandung.
\end{abstract}

Kata Kunci : Trauma, Teknik Disensitisasi Sistematis, Anak. 


\section{PENDAHULUAN}

Keluarga merupakan suatu kelompok yang terdiri dari suami, istri dan anak. Di dalam sebuah keluarga terdapat kerja sama antara satu sama lain, dan mendukung apa yang akan dilakukan oleh anggota keluarganya (Lestari, 2012). Tempat pendidikan pertama bagi anak yaitu keluarga karena peran keluarga berpengaruh kepada tumbuh kembang anak (Tatik, 2014). Orang tua mempunyai kewajiban dalam mendidik karena sangat menentukan bagi kehidupan anak-anaknya baik dari segi pembawaan maupun segi lingkungan (Qadir, 1995). Orang tua merupakan tempat dimana anak mendapatkan pendidikan pertama. Pendidikan ilmu agama juga penting bagi anak. Maka dari itu orang tua wajib menanamkan atau mengenalkan pendidikan moral dan akhlak sejak dini. Karena pendidikan agama sangat penting sebagai pedoman hidup semua individu.

Dalam sebuah kehidupan, moral dan akhlak selalu dibutuhkan setiap waktu. Karena pada dasarnya sebuah keluarga adalah tempat pertama dimana anak menerima sebuah pendidikan dan ilmu guna membentuk kehidupan kedepannya. Seorang suami dan istri harus mampu untuk menjaga keharmonisan rumah tangga mereka. Bimbingan konseling keluarga mempunyai tujuan untuk belajar menghargai anggota keluarga, untuk mencapai suatu keseimbangan untuk keharmonisan keluarga dan sebagai pengaruh dari hubungan pola asuh terhadap anak (L, 2017). Kasus perceraian ini sangat berpengaruh terhadap tumbuh dan kembang dari seorang anak. Selain itu Allah SWT membenci akan hal itu, demikian pula dalam bentuk melarang, seperti firman Allah, yaitu

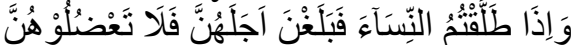

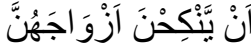

Artinya: "Apabila kamu mentalak isteriisterimu, lalu habis masa iddahnya, Maka janganlah kamu (para wali) menghalangi mereka kawin lagi dengan bakal suaminya". (QS.Al-Baqarah: 232).
Potongan ayat diatas menjelaskan bahwa perceraian itu halal dilakukan tetapi sangat dibenci oleh Allah SWT.

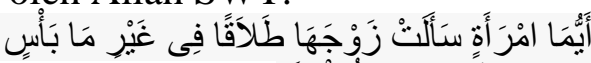

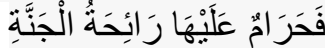

Artinya :"Wanita mana saja yang meminta talak (cerai) tanpa ada alasan yang jelas, maka haram baginya mencium bau surga." (H.R Ibnu Majah).

Hadist diatas menjadi dalil bahwa seorang wanita atau istri dilarang meminta cerai atau menggugat seorang suami, kecuali jika ada alasan yang dibenarkan (Novitasari, n.d.). Maka pikirkan kembali konsekuensinya ketika akan mengambil sebuah keputusan. Bagi seorang anak keterpisahan orangtua merupakan kondisi yang sangat mencemaskan keadaan seorang anak. Dimana dengan adanya kasus perceraian orang tua sangat berdampak buruk terhadap pertumbuhan anak, dimana seorang anak membutuhkan keluarga yang utuh dan harmonis dalam menentukan kehidupan kedepannnya. Sebagaimana telah dijelaskan dalam surat At-Tahrim ayat 6 mengenai peran orang tua, yang berbunyi :

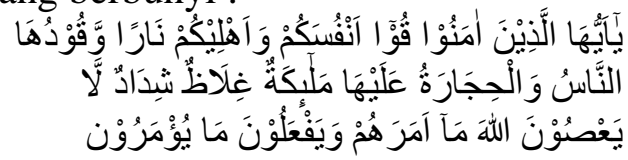

Artinya :" Hai orang-orang yang beriman, peliharalah dirimu dan keluargamu dari api neraka yang bahan bakarnya adalah manusia dan batu; penjaganya malaikatmalaikat yang kasar, keras, dan tidak mendurhakai Allah terhadap apa yang diperintahkan-Nya kepada mereka dan selalu mengerjakan apa yang diperintahkan".

Potongan ayat diatas menjelaskan bahwa setiap orang tua harus berusaha membebaskan diri dan keluarga dari siksaan api neraka. Dalam mendidik anak disesuaikan dengan usianya yang mengarah kepada pembentukan akhlak anak (Padjrin, 2016). Menurut T.O Ihroni bahwa sikap anak kepada orang tuanya yang bercerai tergantung pada penilaian mereka terhadap hubungan orang tua sebelum bercerai, apabila anak merasakan adanya kebahagiaan pada keluarganya 
sebelum keadaan bercerai maka anak akan merasakan trauma yang sangat berat, hal ini bisa terjadi dikarenakan seorang anak belum bisa menerima kondisi dengan orang tuanya yang bercerai (Ihromi, 2004). Menurut Kartini Kartono anak belum bisa menerima perceraian orang tua jelas menimbulkan emosi, rasa tidak percaya diri, kebencian serta perasaan yang cemas (Kartono, 2002) . Adanya perubahan di dalam pola kehidupan anak korban perceraian selalu mengakibatkan meningginya emosi anak (Hurlock, 2002).

Dengan perceraian orang tua anak akan memunculkan perilaku yang negatif bahkan membahayakan untuk anak tersebut. Dalam kasus ini banyak anak yang memunculkan perilaku negatif seperti ketika marah anak membanting barang, ketika cemas anak merasa gugup, kurangnya percaya diri serta anak malas untuk belajar. Karena hal itu muncul ketika keluarganya yang tidak utuh lagi. Apalagi di usia anak yang masih dini sangat berpengaruh besar, dimana mereka masih butuh-butuhnya dengan keluarga untuk pembentukan pola pikir dan karakter. Maka dari itu peneliti menggunakan konseling perilaku (behavior) yang merupakan pendekatan yang didasarkan oleh tingkah laku terhadap lingkungan. Lingkungan dapat membentuk tingkah laku atau kepribadian dari masing-masing individu (Alwisol, 2009). Pola pertumbuhan anak tergantung kepada lingkunganya. Lingkungan keluarga maupun lingkungan teman sebaya.

Konseling perilaku (behavior) ini sesuai dengan permasalahan di lapangan bahwa adanya kasus trauma pada anak karena orang tuanya bercerai. Dimana anak belum bisa menerima kondisi ini. Konseling perilaku ini merupakan konseling yang mempunyai tujuan pada perubahan perilaku. Perilaku bisa dipelajari serta dibentuk dari lingkungan dimana mereka tinggal. Seorang anak mampu membentuk tingkah lakunya dari lingkungan, karena pengaruh lingkungan sangat kuat untuk membentuk rasa percaya diri pada seorang anak. Jadi, lingkungan yang positif sangat penting bagi kehidupan seseorang bahkan lingkungan mempunyai pengaruh yang besar terhadap tingkah laku atau perilaku dari individu. Bahkan konseling perilaku ini mampu untuk mengurangi trauma atau kecemasan pada individu, hal ini diperkuat oleh (Faradillah \& Amriana, 2020; Nasir, 2018).

Konseling perilaku (behavior) mempunyai tiga konsep yaitu $\mathrm{ABC}$ (A) Antecedent merupakan suatu kejadian atau pemicu, (B) Behavior merupakan perilaku yang dimunculkan klien, (C) Consequen merupakan akibat atau konsekuensi dari perilaku yang dimunculkan. Sesuai dengan kasus di lapangan bahwa antecedent peristiwanya adalah perceraian dari orang tua, behavior atau perilaku yang dimunculkan oleh klien ketika marah anak membanting barang, anak menjadi pendiam, saat cemas anak merasa gugup bahkan sulit berkonsentrasi, concequen atau akibat dari perilaku tersebut anak dijauhi teman bahkan anak sulit untuk bersosialisasi. Maka peneliti akan membantu untuk merubah perilaku tersebut yang dilakukan secara bertahap.

Di dalam konseling perilaku (behavior) mempunyai beberapa teknik konseling, sesuai dengan permasalahan penelitian, disini peneliti menggunakan teknik disensitisasi sistematis yang merupakan suatu teknik yang sering digunakan dalam hal konseling perilaku. Pada teknik ini klien diarahkan untuk memunculkan suatu respon yang tidak konsisten dengan kecemasan. Disini klien dilatih untuk santai dan mengasosiasikan keadaan (Gerald, 2009). Teknik ini berpaduan teknik relaksasi dimana dalam proses konseling klien bisa lebih rileks dan nyaman ketika mengutarakan masalahnya. Prinsip utama teknik ini adalah relaksasi dan mengubah respon negatif menjadi respon positif dan hal tersebut dilakukan secara bertahap (Sugiantoro, 2018).

Teknik disensitisasi sistematis merupakan teknik yang tepat untuk 
menangani trauma, kecemasan bahkan phobia. Teknik ini bisa digunakan dalam berbagai hal situasi yang dapat menimbulkan kecemasan. Dalam teknik ini adanya sebuah prosedur dimana klien berulang kali mengingat, membayangkan kejadian yang membangkitkan kecemasan serta menggunakan teknik relaksasi. Dengan adanya kasus trauma pada anak, teknik ini dapat mengurangi rasa trauma pada anak. Trauma merupakan kondisi yang sangat serius jadi dalam penanganan trauma dilakukan secara bertahap, hal ini diperkuat oleh (Erlyn, 2020; Khairunisa et al., 2014).

Maka dari itu untuk mengurangi dampak trauma pada anak korban perceraian dapat dilakukan dengan konseling perilaku kelompok dengan teknik disensitisasi sistematis, layanan ini bertujuan untuk memberikan pelayanan kepada anak secara berkelompok, dan mengentaskan satu persatu permasalahan dari beberapa anak tersebut (Tohirin, 2007). Dengan kondisi mudah marah, merasa cemas bahkan ada yang melampiaskan amarahnya dengan membanting barang. Bahkan anak sulit berkonsentrasi, sulit tidur (insomnia) serta merasa kehilangan makna hidupnya. Hal tersebut menunjukkan bahwa anak mengalami trauma secara psikologis (Hatta, 2016). Hal tersebut terjadi karena anak belum bisa menerima keadaan dengan orang tuanya yang bercerai.

Pada penelitian yang ditemukan di lapangan bahwa dampak trauma pada anak memunculkan perilaku yang berbedabeda. Diantara mereka ada juga yang belum bisa menerima keadaan dan mencemaskan mengenai masa depan mereka, membanting barang ketika marah, sering merasa gugup, memilih untuk menyendiri. Maka dari itu peneliti, melakukan penelitian dengan judul "Efektivitas Konseling Perilaku Dengan Teknik Disensitisasi Sistematis Untuk Mengurangi Dampak Trauma Pada Anak Korban Perceraian Di Desa Bantengan Kecamatan Bandung" dengan judul tersebut dalam penelitian ini mempunyai dua tujuan yaitu bagaimana dampak trauma pada anak korban perceraian di Desa Bantengan Kecamatan Bandung dan Efektif atau tidak konseling perilaku dengan teknik disensitisasi sistematis untuk mengurangi dampak trauma pada anak korban perceraian di Desa Bantengan Kecamatan Bandung.

\section{METODE}

Dalam penelitian ini menggunakan jenis pendekatan kuantitatif. Pendekatan ini suatu metode penelitian yang menekankan pada suatu objek terhadap fenomena sosial atau secara ilmiah. Pendekatan ini mempunyai tujuan untuk mengembangkan teori serta menganalisis fakta-fakta yang telah ditemukan dilapangan (Sugiyono, 2019). Dalam penelitian ini menggunakan desain preeksperimen yang merupakan salah satu metode kuantitatif. Yang digunakan apabila peneliti ingin melakukan percobaan untuk mencari pengaruh variabel independent/treatment/perlakuan tertentu terhadap variabel dependen/hasil dalam kondisi yang terkendalikan.

Peneliti menggunakan jenis eksperimen one group pretest-postest design pada desain ini diberikan angket pre-test, sebelum diberi perlakuan. Dengan begitu hasil perlakuan dapat diketahui lebih akurat, karena peneliti dapat membandingkan dengan keadaan sebelum diberi perlakuan dan sesudah diberi perlakuan. Penelitian ini dilakukan untuk mengurangi dampak trauma pada anak korban perceraian di Desa Bantengan. Dalam pengambilan sampel menggunakan Non Probability Sampling Technique dengan jenis Purposive Sampling (A, 2013). Teknik ini digunakan karena tidak semua subjek dapat diambil dan dijadikan sampel untuk penelitian. Peneliti mengambil sebanyak 40 anak korban perceraian di Desa Bantengan sebagai populasi. Setelah mengetahui hasil pre-test dari populasi tersebut maka dapat mengambil sampel sebagai anak korban perceraian di Desa Bantengan yang mengalami trauma. Instrumen yang 
digunakan dalam penelitian ini adalah lembar angket kuesioner dengan skala likert. Data yang diperoleh dari lapangan kemudian dianalisis dengan uji paired sample t-test dengan aplikasi SPSS versi 26.

Di sini peneliti juga menggunakan empat teknik dalam pengumpulkan data yaitu pertama, observasi yang merupakan sebuah pengamatan pada sesuatu yang akan dijadikan bahan penelitian. Pada hasil pengamatan atau observasi yang dilakukan pada tanggal 16 Desember 2020 bahwa banyaknya kasus perceraian di Desa Bantengan yang menyebabkan kecemasan bahkan trauma pada anaknya. Kedua, dokumentasi merupakan bukti nyata atau tertulis saat penelitian bisa berupa foto atau catatan pada buku (Sugiyono, 2019). Peneliti meminta data cerai di Kantor Desa Bantengan yang dilaksanakan pada tanggal 20 Desember 2020, setelah mendapatkan dokumentasi data cerai, maka peneliti melakukan wawancara. Ketiga, wawancara yang merupakan suatu kegiatan bertanya kepada individu untuk menggali sebuah informasi dengan individu yang bersangkutan. Peneliti melakukan wawancara pada tanggal 5 Januari 2021, hasil yang di dapatkan bahwa banyaknya anak yang memunculkan perilaku maladaptif setelah orang tuanya memutuskan untuk bercerai, dalam pengumpulan data ini peneliti melakukan wawancara kepada 5 orang yang termasuk keluarga dekat yang berinisial MB, EP, $\mathrm{SR}$, YH, LS dengan jenis kelamin perempuan semua dan 3 anak korban perceraian dengan inisial FBA, YS, AKL dengan jenis kelamin peremouan untuk mengetahui data awal. Keempat, angket kuesioner, dimana peneliti menyebar angket pre-test dan post-test kepada anak korban perceraian.

\section{HASIL DAN PEMBAHASAN Hasil}

Penelitian ini dilakukan di Desa Bantengan Kecamatan Bandung. Dengan memberikan layanan konseling perilaku kelompok dengan teknik disensitisasi sistematis untuk mengurangi dampak trauma pada anak korban perceraian. Disini peneliti menggunakan instrumen yaitu angket trauma dengan skala likert. Penelitian ini dilakukan kepada rentang usia anak 8-14 tahun. Peneliti memberikan angket mengenai trauma kepada anak korban perceraian sebanyak 40 anak untuk mengetahui yang memiliki tingkat trauma tinggi. Karena yang menjadi subjek anak, maka dari itu peneliti memberikan angket dengan cara menyebarkan angket ke rumah masing-masing anak. Walaupun penelitian ini bersamaan dengan covid-19 peneliti tetap mematuhi protokol kesehatan dan tetap menjaga jarak. Hasil dari angket dibagi menjadi tiga tingkatan yaitu, tinggi, sedang dan rendah untuk mengetahui hasil secara keseluruhan (Sugiono, 2005). Sebelum melakukan penyebaran angket peneliti melakukan uji ahli angket dan buku panduan eksperimen. Uji ahli yang pertama pada angket trauma. Nama penguji Febri Tri Cahyono, M.Pd dengan ahli bidang Bimbingan dan Konseling pada tanggal 17 Maret 2021. Pada format pengujian angket trauma yang telah dijabarkan oleh peneliti dan akan dilampirkan lembar penilaiannya pada lembar lampiran. Menurut ahli bahwa angket ini layak untuk disebar namun ada beberapa perbaikan mengenai definisi operasional dan ada penambahan item pada beberapa indikator. Uji ahli yang kedua pada buku panduan eksperimen. Nama penguji Muh. Sholihudin Zuhdi, M.Pd dengan bidang ahli Bimbingan dan Konseling pada tanggal 29 Maret 2021. Pada format pengujian buku panduan eksperimen yang telah dijabarkan oleh peneliti dan akan dilampirkan lembar penilaiannya pada lembar lampiran. Menurut ahli bahwa buku panduan eksperimen layak untuk digunakan namun ada beberapa poin yang perlu dibenahi yaitu mengenai konseling perilaku (behavior) lebih disederhanakan lagi dan lebih difokuskan pada teknik disensitisasi sistematis. Hasil dari penyebaran angket dari 40 anak dapat 
dipaparkan dalam tabel kategori responden sebagai berikut :

Tabel 1.

Kategori Responden

\begin{tabular}{|c|c|c|}
\hline Kategori & Jumlah & Skor \\
\hline Tinggi & 18 Anak (45 \%) & $72-96$ \\
\hline Sedang & 22 Anak $(55 \%)$ & $48-71$ \\
\hline Rendah & - & $24-47$ \\
\hline
\end{tabular}

Deskripsi Data Pre-Test dan Data PostTest

Berikut ini hasil paparan data dari instrumen yang digunakan untuk mengurangi dampak trauma pada anak korban perceraian di Desa Bantengan Kecamatan Bandung.

Tabel 2.

Data Pre-Test dan Post-Test Dampak Trauma Anak Korban Perceraian

\begin{tabular}{|c|c|c|c|}
\hline No & Inisial & Skor & Keterangan \\
\hline 1. & NIS & 72 & Tinggi \\
\hline 2. & ES & 72 & Tinggi \\
\hline 3. & YS & 73 & Tinggi \\
\hline 4. & IL & 73 & Tinggi \\
\hline 5. & AKP & 73 & Tinggi \\
\hline 6. & $\mathrm{ZA}$ & 73 & Tinggi \\
\hline 7. & BPD & 74 & Tinggi \\
\hline 8. & LH & 75 & Tinggi \\
\hline 9. & AEL & 75 & Tinggi \\
\hline 10. & IS & 76 & Tinggi \\
\hline 11. & IAPD & 83 & Tinggi \\
\hline 12. & FBA & 82 & Tinggi \\
\hline 13. & OFR & 81 & Tinggi \\
\hline 14. & KAO & 85 & Tinggi \\
\hline 15. & DA & 77 & Tinggi \\
\hline 16. & RDS & 77 & Tinggi \\
\hline 17. & IAR & 79 & Tinggi \\
\hline 18. & AIPY & 79 & Tinggi \\
\hline \multicolumn{2}{|c|}{ Rata-Rata } & 79,375 & Tinggi \\
\hline No & Inisial & Skor & Keterangan \\
\hline 1. & $\mathrm{KAO}$ & 70 & Sedang \\
\hline 2. & IAPD & 71 & Sedang \\
\hline 3. & FBA & 68 & Sedang \\
\hline 4. & OFR & 66 & Sedang \\
\hline 5. & AKP & 69 & Sedang \\
\hline 6. & $\mathrm{DA}$ & 67 & Sedang \\
\hline 7. & AEL & 65 & Sedang \\
\hline 8. & IAR & 70 & Sedang \\
\hline \multicolumn{2}{|c|}{ Rata-Rata } & 68,25 & Sedang \\
\hline
\end{tabular}

Data yang diperoleh dari pemaparan di atas dapat diketahui bahwa ada 18 anak yang memiliki tingkat trauma tinggi. Namun, dengan diadakannya layanan konseling perilaku kelompok maka peneliti mengambil 8 anak untuk diberikan layanan. Anak yang memiliki tingkat trauma tinggi dengan rata-rata skor 
79,375. Dari hasil post-test diatas menunjukkan dampak trauma pada anak korban perceraian di Desa Bantengan Kecamatan Bandung telah menurun setelah diberikan layanan konseling perilaku kelompok dengan teknik disensitisasi sistematis. Data tersebut menunjukkan bahwa sebanyak 8 anak telah mengalami penurunan traumanya dengan kategori sedang dan memiliki rata- rata skor 68,25 dan menunjukkan kategori sedang.

\section{Uji Normalitas}

Uji normalitas memiliki tujuan untuk melihat data tersebar secara normal atau tidak. Uji normalitas dilakukan dengan menggunakan bantuan aplikasi SPSS versi 26.

Tabel 3.

Hasil Uji Normalitas Pre-Test dan Post Test One-Sample Kolmogorov-Smirnov Test

\begin{tabular}{llr} 
& & Unstandardized Residual \\
\hline N & & 8 \\
\hline Normal Parameters & Mean &, 0000000 \\
\cline { 2 - 3 } & Std. & 1,90133512 \\
& Deviation &, 208 \\
\hline Most Extreme & Absolute &, 146 \\
\cline { 2 - 3 } Differences & Positive &,- 208 \\
\cline { 2 - 3 } & Negative &, 208 \\
\hline Test Statistic & &, $200^{\mathrm{c}, \mathrm{d}}$ \\
\hline Asymp. Sig. (2-tailed) & & \\
\hline
\end{tabular}
a. Test distribution is Normal.
b. Calculated from data.
c. Lilliefors Significance Correction.
$\mathrm{d}$. This is a lower bound of the true significance.

Hasil normalitas tersebut menunjukkan nilai signifikan $0,200>0,05$, hal ini dapat disimpulkan bahwa nilai residual tersebar secara normal.

\section{Uji Homogenitas}

Uji homogenitas bertujuan untuk melihat varian yang sama dari sampel yang telah dilakukan penelitian. Uji homogenitas dilakukan menggunakan uji levene dengan bantuan SPSS versi 26.

Tabel 4.

Hasil Uji Homogenitas Pre-Test dan Post-Test Test of Homogeneity of Variances

\begin{tabular}{ll|r|r|r|r} 
& & $\begin{array}{c}\text { Levene } \\
\text { Statistic }\end{array}$ & df1 & df2 & \multicolumn{1}{c}{ Sig. } \\
\hline pretest-posttes & Mean & 4,136 & 1 & 14 &, 061 \\
\cline { 2 - 7 } & Median & 3,756 & 1 & 14 &, 073 \\
\cline { 2 - 7 } & $\begin{array}{l}\text { Median and with } \\
\text { adjusted df }\end{array}$ & 3,756 & 1 & 10,1 &, 081 \\
& trimmed mean & 4,134 & 1 & 14 &, 061 \\
\hline
\end{tabular}

Hasil uji homogenitas diketahui nilai signifikan 0,061 >0,05, hal ini dapat disimpulkan bahwa distribusi data homogen.

\section{Uji Hipotesis}

Uji hipotesis bertujuan untuk melihat hipotesis yang diajukan akan diterima atau ditolak. Uji hipotesis dilakukan 
Tabel 5.

Hasil uji hipotesis Pre-Test dan Post-Test

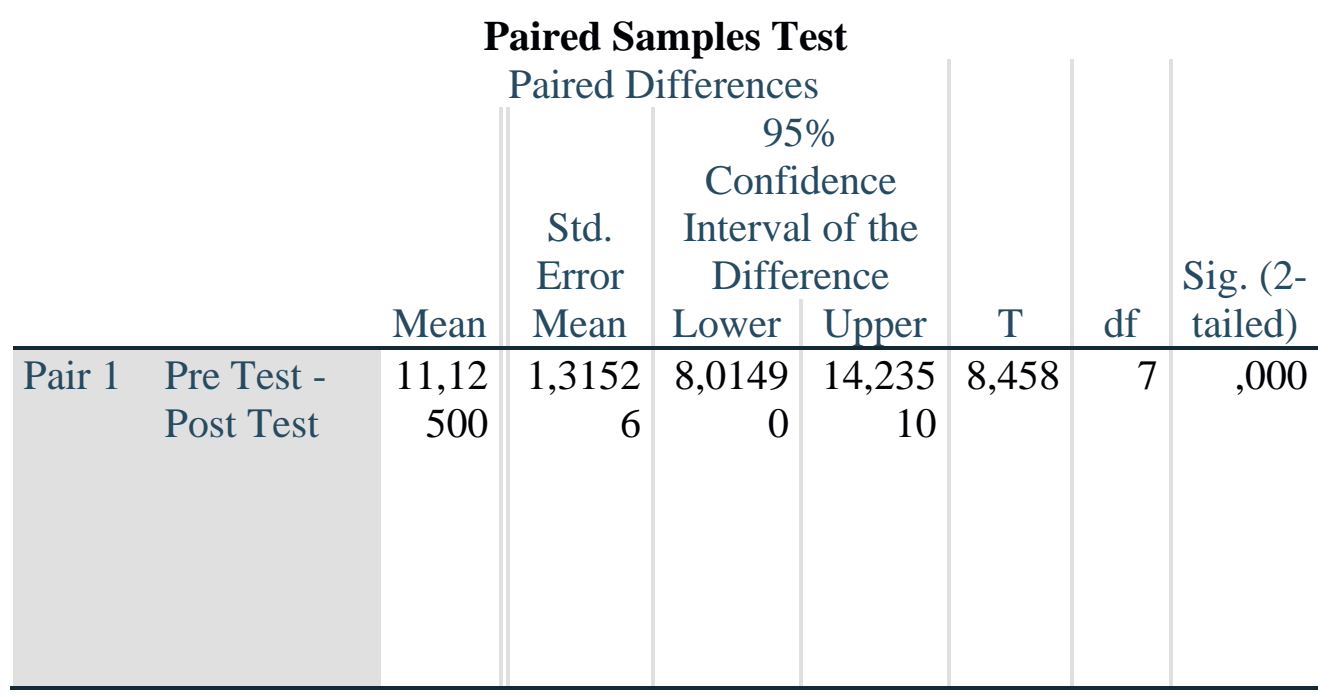

Berdasarkan hasil dari uji hipotesis diketahui nilai signifikan (2-tailed) 0,000 $<0,05$, maka dapat diartikan bahwa terdapat perbedaan yang signifikan antara hasil pre-test dengan hasil post-test. Hal ini dapat disimpulkan bahwa perlakuan yang diberikan memiliki pengaruh terhadap masing-masing variabel. Sehinga dalam penelitian ini $\mathrm{Ha}$ diterima yaitu penerapan konseling perilaku kelompok dengan teknik disensitisasi sistematis dapat mengurangi dampak trauma anak korban perceraian di Desa Bantengan Kecamatan Bandung serta konseling perilaku dengan teknik disensitisasi sistematis efektif digunakan untuk mengurangi dampak trauma pada anak korban perceraian di Desa Bantengan Kecamatan Bantengan.

\section{Pembahasan}

\section{Dampak trauma anak korban perceraian}

Dari hasil angket yang telah disebar untuk 40 anak korban perceraian, diketahui hasil presentase $45 \%$ menunjukkan sebanyak 18 anak dalam kategori tinggi dan $55 \%$ menunjukkan sebanyak 22 anak dalam kategori sedang. Sebanyak 18 anak yang mempunyai dampak trauma tinggi, namun dalam pemberian treatment tidak bisa diambil semuanya melainkan hanya sebagian. Karena menggunakan layanan konseling kelompok dengan batas atas 12 orang, maka dari itu peneliti mengambil sebanyak 8 anak untuk dijadikan sampel dan diberi perlakuan dengan layanan konseling kelompok dengan teknik disensitisasi sistematis. Angket trauma ini diberikan kepada anak yang rentang usianya 8-14 tahun. 1 anak berusia 8 tahun berinisal KAO dengan jenis kelamin perempuan, 5 anak berusia 10 tahun berinisial IAPD (perempuan), AKP (Lakilaki), DA (laki-laki), AEL (perempuan) dan IAR (perempuan). Serta 2 anak berusia 12 tahun berinisial FBA dan OFR dengan jenis kelamin perempuan. Selisih rentang usia perceraian yang terjadi ada yang 2 bulan bahkan ada yang 1 tahun setelah orangtuanya bercerai. Karakteristik dari 8 anak berbeda-beda, ada yang pendiam, sulit berkonsetrasi, mudah marah bahkan ada juga yang selalu membanting barang disaat dirinya merasa terganggu atau marah. Dimana mereka belum mampu untuk mengontrol emosinya. Karakteristik dari perceraian orangtuanya. Bahwa dari 8 orangtua anak tadi memiliki kondisi yang berbeda. Mengenai rentang usia dan status ada yang berusia 27-30 berjumlah 3 orang dengan 
status sudah menikah dengan jenis kelamin perempuan semua yang berinisial KM, SY dan UM, kemudian 5 orang berusia 29-32 dengan jenis kelamin 3 lakilaki dan 2 perempuan dengan status single dan ada yang menjadi seorang TKW yang berinisial SY, YH, SS (laki-laki) dan AY, SL (perempuan dan menjadi TKW).
Layanan
konseling
kelompok

merupakan suatu upaya pemberian bantuan untuk memecahkan masalah klien dengan memanfaatkan dinamika kelompok (Juntika, 2009). Tujuan dari layanan konseling perilaku kelompok ini untuk mengembangkan kemampuan sosialisasi klien, khususnya dalam hal berkomunikasi. Dalam pelaksanaan layanan konseling kelompok dapat diketahui bahwa hampir semua anak memiliki keinginan untuk keluar dari rasa cemas yang berlebihan yang mampu menyebabkan trauma. Trauma merupakan suatu kondisi menghadapi atau merasakan sebuah kejadian atau serangkaian kejadian yang berbahaya, baik bagi fisik maupun psikologis seseorang, yang membuatnya tidak lagi merasa aman, berbahaya bagi individu tersebut serta pengalaman yang sangat menyedihkan, hal ini diperkuat oleh (Achamanto, 2010; Kartono, 1989). Trauma suatu hal yang sangat membahayakan bagi yang mengalaminya maka dari itu, harus segera disembuhkan.

Pada kasus yang terjadi dilapangan termasuk trauma psikologis karena adanya kondisi atau peristiwa yang menekan klien sehingga mereka merasa terpuruk akan hal tersebut. Dengan begitu klien memunculkan beberapa perilaku maladaptif di kehidupan sehari-harinya. Perceraian pada orang tua sangat berpengaruh terhadap anak, karena belum tentu anak bisa menerima keadaan dengan orang tua yang bercerai, tanpa berpikir panjang orang tua mengambil keputusan yang dapat mempengaruhi perkembangan anak. Terutama dalam hal membentuk karakter dan pola pikir anak. Seorang anak tentu saja akan berpikir bahwa orang tuanya tidak peduli dengannya, sehingga mereka melampiaskan dengan memunculkan perilaku negatif. Seperti halnya ketika anak marah mereka membanting barang dan hal ini membuat anak akan dijauhi teman sebayanya, hal ini diperkuat oleh (Aziz, 2015; Dahwadin et al., 2020).

Trauma merupakan pengalaman masa lalu yang tidak menyenangkan, bisa seperti perceraian, terkena bencana alam, dll. Dengan kejadian tersebut maka akan menimbulkan dampak terhadap individu yang mengalaminya. Dampak yang menyebabkan kondisi dari seorang anak menurun mengenai kepercayaan diri, emosi dari seorang anak, rasa cemas yang berlebihan serta dalam hal motivasi belajar anak. Dengan kondisi orang tua bercerai maka anak sulit untuk mengembangkan pemikirannya serta anak cenderung memunculkan perilaku yang menyimpang. Orang tua bertanggung jawab terhadap anak dalam hal pengasuhan sehingga mempengaruhi tingkat perkembangan pada anak. Maka dari itu dengan kondisi orang tua yang bercerai akan mengganggu perkembangan pada anak (Marisa et al., 2018). Dampak trauma yang pertama yaitu mengenai kepercayaan diri yang merupakan keyakinan yang berada dalam diri individu dan membuatnya mampu dalam mencapai tujuan hidupnya. Disini peneliti melihat bahwa dengan adanya perceraian orang tua, menyebabkan klien merasa kurang percaya diri, mereka merasa malu dengan keadaan orang tua yang bercerai sehingga mereka merasa tidak yakin dengan kehidupan di masa depannya, hal ini diperkuat oleh (Marta \& Supriyo, 2013; Mone, 2019).

Kedua, kecemasan yang merupakan suatu bentuk perasaan dimana individu merasa terancam atau memikirkan sesuatu secara berlebihan, sehingga rasa cemas yang muncul secara berlebihan akan memunculkan beberapa perilaku (Rosmawati, 2017). Disini ketika merasa cemas klien memunculkan perilaku merasa gugup, sulit untuk berkonsentrasi, mengalami masalah dalam kesehatannya seperti mudah merasa lelah dan sering sakit. Ketiga, emosi merupakan suatu 
perasaan yang dimunculkan oleh setiap individu. Dimana dengan kondisi orang tua yang bercerai, anak akan mengalami beberapa perubahan emosi atau perasaan, seperti anak mudah marah, anak sulit untuk membedakan perasaan senang maupun sedih, bahkan mereka sulit untuk menempatkan perasaannya di dalam kondisi apapun, hal ini diperkuat oleh (Filtri, 2017). Keempat, mengenai motivasi yang bisa dikatakan sebuah dukungan atau semangat untuk melakukan suatu tindakan. Yang digunakan untuk mencapai suatu tujuan tertentu. Salah satunya dalam hal pembelajaran, belajar sangat penting bagi semua orang hal ini bisa diterapkan sejak usia dini. Perilaku yang dimunculkan oleh anak adalah ketika belajar anak sulit menerima materi yang telah disampaikan oleh gurunya, bahkan anak lebih suka bermain hp dari pada belajar. Hal ini terjadi dikarenakan tidak adanya motivasi atau dorongan yang berasal dari orang tua atau keluarganya (Muhammad, 2017). Fokus dampak trauma yang ingin dihilangkan dari anak atau perilaku yang akan diubah adalah disaat marah anak membanting barang dimana ketika anak marah mereka mempunyai kehendak untuk membanting barang yang ada di sekitarnya, menjadi anak yang pendiam karena kurangnya percaya diri atau bahkan malu dengan keadaan orangtuanya yang bercerai, anak yang sulit berkonsentrasi dan bersosialisasi saat di keramaian.

\section{Konseling Perilaku Dengan Teknik Disensitisasi Sistematis Untuk Mengurangi Dampak Trauma Pada Anak Korban Perceraian Di Desa Bantengan Kecamatan Bandung}

Hasil penelitian menunjukkan terdapat perbedaan mengenai perilaku dari anak sebelum diberikan layanan dan sesudah diberikan layanan. Dapat diketahui rata-rata hasil layanan yaitu 79,375 (pre-test) dan 68,25 (post-test). Hal tersebut dapat diartikan bahwa dampak trauma pada anak korban perceraian telah menurun setelah mendapatkan layanan konseling perilaku kelompok dengan teknik disensitisasi sistematis. Penelitian ini bertujuan untuk mengetahui bagaimana dampak trauma pada anak korban peceraian dan untuk mengetahui efektifvitas konseling perilaku dengan teknik disensitisasi sistematis untuk mengurangi dampak trauma pada anak korban perceraian di Desa Bantengan Kecamatan Bandung. Hal ini dapat dibuktikan dari hasil pre-test dan post-test menunjukkan signifikansi (2-failed) sebelum diberi perlakuan dan sesudah diberi perlakuan yaitu $0,000<0,05$. Hasil tersebut menjelaskan bahwa terdapat perbedaan dari layanan yang telah diberikan. Di dalam penelitian ini $\mathrm{H}_{\mathrm{a}}$ diterima yaitu penerapan layanan konseling perilaku kelompok dengan teknik disensitisasi sistematis dapat menurunkan dampak trauma pada anak korban perceraian. Dapat juga diartikan bahwa teknik disensitisasi sistematis efektif untuk mengurangi dampak trauma pada anak korban perceraian di Desa Bantengan Kecamatan Bandung. Konseling perilaku (behavior) mempunyai beberapa tahapan konseling yaitu yang pertama, tahap assesment. Kedua, menetapkan tujuan (goal setting). Ketiga, implementasi teknik (technique implementation). Keempat, evaluation termination. Kelima, feedback atau penutup konseling (Gerald, 2009).

Di dalam menggunakan teknik disensitisasi sistematis melibatkan sistematika teknik-teknik relaksasi (Willis, 2010). Jadi, saat layanan konseling perilaku kelompok peneliti juga menggunakan relaksasi supaya klien tetap merasa nyaman. Dimana teknik ini diberikan saat klien merasa kurang nyaman serta gelisah. Jadi disini adanya dukungan dari peneliti untuk klien atau anak sehingga mereka mampu untuk keluar dari kondisi yang tidak diinginkan. Tidak lupa peneliti menggunakan teknik relaksasi ketika anak mulai merasa tidak nyaman, bahkan rasa bosan muncul dalam layanan konseling kelompok maka dari itu peneliti juga mengadakan permainan 
kelompok sebagai selingan atau permainan supaya anak tidak merasa bosan. Permainan kelompok yang efektif mempunyai ciri-ciri yang sederhana, tidak membuat bosan, menghasilkan suasana yang nyaman, serta anggota kelompok menjadi lebih (Tohirin, 2007). Banyak dampak yang menyebabkan anak menjadi trauma yaitu faktor dari keluarga dan faktor dari teman sebaya (Achamanto, 2010). Adanya pengasuhan yang kasar saat orang tua bercerai, anak merasa malu ketika berada di lingkungan sekolah atau lingkungan bermainnya serta mengenai kehidupan sosialnya (Ahmadi, 1991).

Dengan adanya hasil atau bukti diatas bisa dikatakan bahwa konseling perilaku dengan teknik disensitisasi sistematis, efektif serta mampu untuk mengurangi dampak trauma pada anak karena dalam pemberian angket trauma terdapat empat indikator yaitu mengenai kepercayaan diri, emosi, kecemasan dan motivasi dalam belajar. Dimana masingmasing indikator dapat mewakili kondisi yang sedang dialami oleh anak. Maka dari itu anak yang memiliki dampak trauma tinggi karena anak belum mampu untuk mengkondisikan rasa emosi dan cemas, serta kurangnya percaya diri pada anak dan belum mampu menerapkan motivasi untuk belajar dalam kehidupan sehari-hari. Namun setelah mendapatkan perlakuan dampak trauma yang dialami anak bisa menurun walaupun masih dalam kategori sedang, karena mereka mau untuk belajar serta menempatkan diri mereka sesuai keadaan yang ada. Secara pelan-pelan mereka mampu untuk mengkondisikan emosinya, kecemasannya dan menumbuhkan rasa percaya diri serta motivasi dalam belajar, hal ini diperkuat oleh (Fatchurahman \& Pratikto, 2012).

Dari hasil penelitian ini dapat di dukung oleh penelitian yang sebelumnya, bahwa proses bimbingan dan konseling dengan teori konseling perilaku dapat mengurangi emosi pada anak serta konseling perilaku merupakan konseling yang tepat untuk menangani siswa yang indisipliner di sekolah (Soviyanti, 2019;
Wahyudi, 2018). Untuk itu konseling perilaku (behavior) dengan teknik disensitisasi sistematis bisa dijadikan solusi untuk mengurangi tingkah laku yang maladaptif.

Keberhasilan penelitian ini tidak sepenuhnya berasal dari konseling kelompok yang telah dilakukan. Namun, hal ini terjadi karena adanya keinginan dari anak untuk keluar dari permasalahan serta anak ingin mengubah perilakunya menjadi lebih baik. Selain itu juga adanya motivasi dalam diri individu untuk terus berkembang masa depannya.

\section{KESIMPULAN}

Berdasarkan dari hasil penelitian yang telah dilakukan, maka kesimpulan secara umum yaitu, layanan konseling perilaku kelompok dengan teknik disensitisasi sistematis dapat mengurangi dampak trauma pada anak korban perceraian di Desa Bantengan Kecamatan Bandung dan teknik disensitisasi sistematis efektif untuk mengurangi dampak trauma pada anak korban perceraian. Sedangkan kesimpulan secara khusus yaitu terdapat perbedaan hasil dari tingkat perilaku dampak trauma pada anak sebelum dan sesudah diberikan perlakuan layanan konseling perilaku kelompok dengan teknik disensitisasi sistematis, dimana rata-rata hasil dari dampak trauma anak menurun setelah mendapatkan perlakuan. Dari hasil uji hipotesis menggunakan uji paired sample t-test diperoleh nilai signifikansi yaitu (2-tailed) $0,000<0,05$ yang dapat diartikan bahwa $\mathrm{H}_{\mathrm{a}}$ diterima yaitu penerapan layanan konseling perilaku kelompok dengan teknik disensitisasi sistematis dapat mengurangi dampak trauma pada anak korban perceraian di Desa Bantengan Kecamatan Bandung.

\section{UCAPAN TERIMA KASIH}

Dengan terselesaikannya penulisan artikel jurnal sebagai laporan tugas akhir, sebagai bentuk rasa syukur penulis mengucapkan terima kasih untuk lembaga atau instansi yang telah bersedia memberikan bantuan seperti IAIN 
Tulungagung dan Desa Bantengan yang telah memberi ijin kepada penulis untuk melakukan penelitian. Selain itu, penulis juga mengucapkan syukur alhamdulilah kepada Allah SWT dan terima kasih yang sebesar-besarnya terutama kepada kedua orang tua (Bapak Sumarji dan Ibu Sunarsih), dosen pembimbing (Bapak Wikan Galuh Widyarto, M.Pd) serta sahabat saya Laras Ayu Kinanthi dan teman-teman yang telah memberikan banyak bantuan, dukungan serta motivasi maka dari itu penulis mampu menyelesaikan artikel jurnal ini dengan baik.

\section{PERNYATAAN PENULIS}

KONTRIBUSI

Penulisan artikel ini dilakukan oleh dua orang yaitu YDS dan WGW. Dalam hal ini YDS berperan dalam hal pengumpul data dan penulisan hasil data yang telah diperoleh ketika di lapangan. Sedangkan WGW berperan dalam hal memberikan arahan dan membantu menyempurnakan penulisan artikel jurnal ini.

\section{REFERENSI}

A, Y. (2013). Metode Penelitian:

Kuantitatif, Kualitatif dan Penelitian

Gabungan. UNP Press.

Achamanto, M. (2010). Pemulihan

Trauma. Panduan.

Agama, R. D. (2001). Kompilasi Hukum Islam.

Ahmadi, A. (1991). Psikologi Belajar.

Rineka Cipta.

Alwisol. (2009). Psikologi Kepribadian.

UMM Press.

Aziz, M. (2015). Perilaku Sosial Anak

Remaja Korban Broken Home Dalam

Berbagai Perspektif. Jurnal Al

Ijtimaiyyah, 1(1), 30-50.

Dahwadin, D., Syaripudin, E. I.,

Sofiawati, E., \& Somantri, M. D.

(2020). Hakikat Perceraian

Berdasarkan Ketentuan Hukum Islam

Di Indonesia. YUDISIA : Jurnal

Pemikiran Hukum Dan Hukum Islam, 11(1), 87. https://doi.org/10.21043/yudisia.v11i 1.3622

Erlyn, N. (2020). Pengaruh Teknik

Disensitisasi Sistematis Untuk

Pengurangan Kecemasan Peserta

Didik Dalam Menghadapi Ujian

Kelas VII SMP Negeri 06 Kotabumi

Lampung Utara Tahun Pelajaran

2019/2020. Universitas Islam Negeri

Raden Intan Lampung.

Faradillah, S. S., \& Amriana. (2020).

Cognitive-Behavioral Therapy dengan Teknik Thought Stopping untuk Menangani Trauma Psikologis Mahasiswa yang Mengalami Broken Home. Prophetic: Professional, Empathy and Islamic Counseling Journey, 3(1), 83-94.

Fatchurahman, M., \& Pratikto, H. (2012). Kepercayaan Diri, Kematangan Emosi, Pola Asuh Orang Tua Demokratis dan Kenakalan Remaja. Persona:Jurnal Psikologi Indonesia, 1(2).

https://doi.org/10.30996/persona.v1i2 .27

Filtri, H. (2017).

PERKEMBANGANEMOSIONAL

ANAK USIA DINI USIA 5-6

TAHUN DITINJAU DARI IBU

YANG BEKERJA Title. PAUD

Lectura: Jurnal Pendidkan Anak

Usia Dini, 1(1), 32-37.

Gerald, C. (2005). Teori dan Praktek Konseling \& Psikoterapi. PT. Refika Aditama.

Gerald, C. (2009). Teori dan Praktek Konseling \& Psikologi. PT. Refika Aditama.

Hatta, K. (2016). Trauma Dan

Pemulihannya. Dakwah Ar-Raniry

Press.

dakwaharranirypress@yahoo.com

Hurlock, E. B. (2002). Psikologi

Perkembangan Suatu Pendekatan

Sepanjang Rentang Kehidupan.

Erlangga.

Ihromi, T. . (2004). Bunga Rampai Sosiologi Keluarga. Yayasan Obor Indonesia.

Juntika, A. (2009). Strategi Layanan 
Bimbingan dan Konseling. Refika Aditama.

Kartono, K. (1989). Hygiene Mental dan Kesehatan Mental Dalam Islam. Mandar Maju.

Kartono, K. (2002). Patologi Sosial 2: Kenakalan Remaja. Grafindo Persada.

Khairunisa, Kiranida, O., Marjo, H. K., \& Hanim, W. (2014). Bimbingan Kelompok Menggunakan Teknik Desensitisasi Sistematik Untuk Menurunkan Tingkat Glossophobia Peserta Didik Sekolah Menengah Atas (SMA). Jurnal Selaras, 47-56.

L, S. (2017). Bimbingan Konseling Keluarga. Mimbar Pustaka.

Lestari, S. (2012). Psikologi Keluarga. Kencana.

Manribu, S. A. dan. (1996). Tekhnik dan Laboratorium Konseling.

Marisa, C., Fitriyanti, E., \& Utami, S. (2018). Hubungan Pola Asuh Orangtua dengan Motivasi Belajar Remaja. Jurnal Konseling Dan Pendidikan, 6(1), 25. https://doi.org/10.29210/118700

Marta, D., \& Supriyo, D. (2013). Kepercayaan Diri Ditinjau dari Pola Asuh Orang Tua pada Siswa Kelas VII (Studi Kasus). Indonesian Journal of Guidance and Counseling, 2(4), 9-16.

Mone, H. F. (2019). Dampak perceraian orang tua terhadap perkembangan psikososial dan prestasi belajar. Harmoni Sosial: Jurnal Pendidikan IPS, 6(2), 155-163. https://doi.org/10.21831/hsjpi.v6i2.20 873

Muhammad, M. (2017). Pengaruh Motivasi Dalam Pembelajaran. Lantanida Journal, 4(2), 87. https://doi.org/10.22373/lj.v4i2.1881

Nasir, A. (2018). Konseling Behavioral: Solusi Alternatif Mengatasi Bullying Anak Di Sekolah. Konseling Edukasi: Journal of Guidance and Counseling, 2(2), 67-82.

Novitasari, D. (n.d.). Maraknya Istri Menggugat Cerai Suami di
Pengadilan Agama Padang.

Https://Sumbar.Kemenag.Go.Id/v2/P ost $/ 2056$.

Padjrin, P. (2016). Pola Asuh Anak dalam Perspektif Pendidikan Islam.

Intelektualita, 5(1), 1.

https://doi.org/10.19109/intelektualita .v5i1.720

Qadir, J. abdul. (1995). Keluarga Sakinah. PT. Bina Ilmu.

Ramadhani, P. E., \& Krisnani, H. (2019). Analisis Dampak Perceraian Orang Tua Terhadap Anak Remaja. Focus : Jurnal Pekerjaan Sosial, 2(1), 109. https://doi.org/10.24198/focus.v2i1.2 3126

Rosmawati. (2017). PENERAPAN LAYANAN KONSELING UNTUK MENGATASI KECEMASAN SISWA. Jurnal Konseling Andi Matappa, 1(4), 39-45.

Soviyanti, P. (2019). BIMBINGAN DAN KONSELING ISLAM DENGAN TERAPI BEHAVIOR UNTUK MENGURANGI EMOSI NEGATIF ANAK PEREMPUAN SETELAH AYAHNYA MENINGGAL (STUDI KASUS DESA JEMIRAHAN KECAMATAN JABON KABUPATEN SIDOARJO).

Sugiantoro, B. (2018). Teknik

Desensitisasi Sistematis (Systematic

Desensitization) dalam Mereduksi Gangguan Kecemasan Sosial (Social Anxiety Disorder) yang dialami Konseli. Nusantara of Research, 5(2), 72-82. https://doi.org/10.29407/nor.v5i2.130 78

Sugiono. (2005). Statistik untuk penelitian. Alfabeta.

Sugiyono. (2019). Metode Penelitian Kuantitatif Kualitatif \& $R \& D$. Alfabeta.

Tatik, M. (2014). Psikologi Keluarga. UIN Sunan Ampel Press.

Tohirin. (2007). Bimbingan dan Konseling Di Sekolah dan Madrasah Berbasis Integrasi. PT. RajaGrafindo Persada.

Wahyudi, M. A. S. (2018). Konsep Pendekatan Behavior Dalam 
Menangani Perilaku Indisipliner Pada

Siswa Korban Perceraian. Jurnal

Bimbingan Dan Konseling Islam,

8(1), 35 .

https://doi.org/10.29080/jbki.v8i1.55

Willis, S. (2010). Konseling Individual

Teori dan Praktek. Alfabeta. 